\title{
DEVELOPMENT OF TOEIC TEST-TAKING SKILLS BY APPLYING KAHOOT! AS A REMEDIAL TEACHING TOOL
}

\author{
Kanokrat Kunasaraphan
}

\author{
Suan Sunandha Rajabhat University, Bangkok, Thailand
}

The purpose of this study is to investigate and compare TOEIC scores before and after applying Kahoot! as a remedial teaching tool on the sample of 180 (6 groups, 30 students each group) first-year students enrolled on the Airline Business Program in the International College, Suan Sunandha Rajabhat University. The research instruments in this study were TOEIC test and all questions on Kahoot! to improve students' skills in TOEIC test reading section. The researcher applied Kahoot! at the end of 15 classes, 15-20 minutes each class. The researcher analyzed students' TOEIC scores before and after applying Kahoot! as a remedial teaching tool by calculating TOEIC scores and percentage.

The findings show that all average scores in the semester 1/2018 were higher than the score in semester 3/2017 which the score in listening section was more than the one in the reading section. Similarly, in each group, the average score in semester 1/2018 was higher than the score in semester 3/2017 while the score in listening section was more than the one in reading section. Generally, students' TOEIC scores before applying Kahoot! were higher than after applying Kahoot!. The percentage of difference score before and after employing Kahoot! in the reading section was more than in the listening section. The group that obtained the highest percentage of difference score was group 6, followed by groups 5, 2, 4, 3 and 1, respectively. In part of the listening section, the group that obtained the highest percentage of difference score was group 4, followed by groups 6, 2, 5, 3 and 1, respectively. In part of the reading section, the group that obtained the highest percentage of difference score was group 5, followed by groups 6, 3, 2, 4 and 1, respectively.

From Kahoot! score results, the researcher found that the average score, including the percentage of correct answers on Kahoot! tends to get higher. Therefore, lecturers should promote and develop students' TOEIC test-taking skills in part of its listening and reading sections by means of integrating Kahoot! or other active learning strategies in the everyday classroom.

Keywords: remedial teaching; TOEIC; Kahoot!; test-taking skills; college students; Thailand

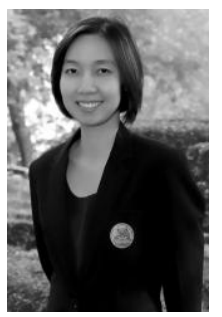

\section{Kanokrat Kunasaraphan}

PhD, Lecturer on Mathematics Education in International College, Suan Sunandha Rajabhat University, Bangkok, Thailand

Research interests: mathematic, English education, Educational management

Published about 25 papers in Thai and International journals

E-mail: kanokrat.ku@ssru.ac.th 


\section{DEVELOPMENT OF TOEIC TEST-TAKING SKILLS BY}

\section{Introduction}

English language is an essential tool for people to communicate all over the world and is the most commonly spoken language in the world these days. It is the language of science, of aviation, computers, diplomacy, and tourism. Knowing English increases one's chances of getting a good job, in a multinational company within your own home country and of finding a work abroad. In education, English helps people find an appropriate school and course to suit their academic needs.

This is directly applicable to Thai students, as most of them aim to get a great job at the international level or continue studying abroad. Therefore, it is vitally necessary for Thai students to have good English language skills, including those in listening, speaking, reading and writing. English reading and writing skills are usually the most complicated ones for the language learners who study English as a second or foreign language (Torwong, 1995).

Following the graduation requirement of the International College, Suan Sunandha Rajabhat University, graduates must meet the requirement of English proficiency. This is checked via Test of English for International Communication (TOEIC) or other similar tests. Most of local students choose TOEIC as an exit exam for graduation. They are required to have the TOEIC score of 600.

TOEIC consists of two sections, listening and reading, each having seven parts. Reading section is the most difficult for students, however, it is also the part that may get not too difficult if students regularly practice to improve their score. Therefore, the purpose of this study is to investigate students' results in TOEIC and to compare their skills in TOEIC test-taking before and after applying Kahoot! as a remedial teaching tool. The results may be further used as guidelines for effective support and improvement of students' English testtaking skills, especially in the case of TOEIC.

\section{Literature \& Theory}

TOEIC Listening and Reading test measures everyday English listening and reading skills needed for work in the international environment. Test questions simulate real-life situations that are relevant to the global workplace. TOEIC Listening and Reading scores provide meaningful feedback about the test-taker's strengths and weaknesses, along with the description of the skills typical for test-takers at various levels. TOEIC test provides fair and valid assessment of English-language listening and reading skills for the workplace.

Employers worldwide use this test to determine who can communicate effectively in English across borders and cultures with coworkers and clients. For more than 40 years, TOEIC Listening and Reading test has been helping millions of people to qualify for promising employment opportunities around the world. TOEIC scores can you a stronger candidate for job opportunities within global organizations through demonstrating your ability to communicate across borders and cultures with coworkers and clients. It also positively affect hiring decisions and other employment opportunities (Educational Testing Service, 2018).

According to the Educational Testing Service (2018), TOEIC is a paper-and-pencil, multiple-choice assessment. There are two sections in it, 100 questions each. The test takes approximately two hours and a half with 45 minutes for Section I (Listening) and 75 minutes 
for Section II (Reading). In Section I test-takers listen to a variety of questions and short conversations recorded in English, then answer questions based on what they have heard.

This section is divided into the following parts: Part 1: Photographs, Part 2: QuestionResponse, Part 3: Conversations, and Part 4: Short Talks. In Section II, Reading, test-takers read a variety of materials and respond at their own pace. Parts belonging to this section are as follows: Part 5: Incomplete Sentences, Part 6: Text Completion, and Part 7: Reading Comprehension.

TOEIC as a whole gives a score between 10 and 990: 905-990 stands for International Proficiency; 785-900 is Working Proficiency Plus; 605-780 means Limited Working Proficiency; 405-600 is for Elementary Proficiency Plus; 255-400 assumes Elementary Proficiency; 185-250 means Memorized Proficiency; and finally, 10-180 stands for No Useful Proficiency.

To investigate and compare students' TOEIC test-taking skills in this study, the researcher applied Kahoot! as a remedial teaching tool for encouraging students to practice TOEIC exercise in the part of incomplete sentences and text completion. They have lots of fun and gain more understanding about English grammar, especially as to incomplete sentences and text completion.

Kahoot! is a tool used for motivating students and reinforcing learning. It is a game based classroom response system played by the whole class in real time. Students answer the questions projected on the screen using their smartphones, tablets or computers to provide online answers. Teachers can measure students' understanding of a topic by using Kahoot! as the game records all students' answers to all questions as well as shows how quickly they respond. There are different types of Kahoot!. This game can be used as a tool for quizzes, surveys, jumbles, discussions and challenges.

Kahoot! offers many benefits in the classroom, for both teachers and students. It is a great way to keep students engaged because it focuses on social learning and makes the whole process fun. Teachers can use Kahoot! as a class starter to get students engaged at the beginning of an academic hour. They can also use it as a form of pre-assessment to see how much students know about the new content. Moreover, it can be used throughout a lesson to measure student engagement and understanding. Kahoot! gives teachers the ability to track student performance and then to make adjustments in teaching or reteaching on some topics (Kahoot!, 2018).

In this study specifically, the researcher applied Kahoot! as quizzes to investigate and compare students' TOEIC test-taking skills.

\section{Methods}

Population in this study was the first-year students studying Airline Business in the International College, Suan Sunandha Rajabhat University, academic year 2018. The sample of this research consisted of 180 first-year students. These students were divided into six groups, 30 students in each group.

The instruments applied in this study were the samples of TOEIC tests and Kahoot! exercises.

The researcher collected data following such steps:

1. Academic Affairs of International College, Suan Sunandha Rajabhat University conducted a TOEIC test in the semester 3/2017. 


\section{DEVELOPMENT OF TOEIC TEST-TAKING SKILLS BY}

2. Academic Affairs of International College, Suan Sunandha Rajabhat University reported TOEIC score results.

3. The researcher analyzed TOEIC score results by dividing test sections - listening and reading separately.

4. The researcher designed own remedial teaching by using Kahoot!.

According to the analyzed test results, the students got the lowest scores in section II, Reading, therefore, the researcher designed questions in Kahoot! targeting primarily reading. The researcher applied Kahoot! as a remedial teaching tool in every class (15 classes in total), about 15 minutes before finishing every class. The exercise usually had 3-5 items of reading section, such incomplete sentences and text completion parts.

Implementation of remedial teaching in this particular case can be described as follows:

1) The researcher allowed students to access the website, www.kahoot.it;

2) The students answered each question in a limited time (20 seconds and 10 seconds, depending on a task);

3) The researcher explained the correct answer to each question in detail;

4) The researcher gave students opportunities to ask some questions that they do not understand about the correct answer;

5) The researcher explained more, if needed, about English usage in other contexts and situations.

5. Academic Affairs of International College, Suan Sunandha Rajabhat University conducted another TOEIC test in the semester 1/2018.

6. Academic Affairs of International College, Suan Sunandha Rajabhat University reported the second round of TOEIC results.

7. The researcher compared students' TOEIC score results before and after applying Kahoot! as a remedial teaching tool.

8. The researcher reported the results, conclusions and discussions of this study.

Analysis of the data was following such logic:

1. The researcher analyzed students' TOEIC score results.

2. The researcher compared students' TOEIC score results divided as before and after.

3. The researcher analyzed students' Kahoot! average score results and the percentage of students' correct and wrong answers.

\section{Results}

According to objective 1, the researcher has analyzed TOEIC score results of the firstyear students of the program Airline Business, International College, Suan Sunandha Rajabhat University in semester 3 academic year 2017, before applying Kahoot! as a remedial tool and then in semester 1 academic year 2018, already after applying Kahoot! as a remedial teaching tool. There were six groups of students, 30 students in each group. So, the total number of students is 180 students. The results are shown in Tab. 1. 
Table 1 - TOEIC Results of First-Year Students, International College, Suan Sunandha Rajabhat University

(Source: made by the author)

\begin{tabular}{|c|c|c|c|c|c|c|}
\hline \multirow{2}{*}{ Groups } & \multicolumn{3}{|c|}{$\begin{array}{c}\text { TOEIC Average Score Results } \\
\text { Semester } 3 / 2017\end{array}$} & \multicolumn{3}{|c|}{$\begin{array}{c}\text { TOEIC Average Score Results } \\
\text { Semester } 1 / 2018\end{array}$} \\
\hline & $\begin{array}{l}\text { Listening } \\
\text { (495) }\end{array}$ & $\begin{array}{c}\text { Reading } \\
(495)\end{array}$ & $\begin{array}{l}\text { Total } \\
(990)\end{array}$ & $\begin{array}{l}\text { Listening } \\
\text { (495) }\end{array}$ & $\begin{array}{c}\text { Reading } \\
(495)\end{array}$ & $\begin{array}{l}\text { Total } \\
\text { (990) }\end{array}$ \\
\hline 1 & 199 & 92 & 291 & 233 & 121 & 354 \\
\hline 2 & 172 & 95 & 267 & 223 & 131 & 354 \\
\hline 3 & 178 & 78 & 256 & 215 & 117 & 332 \\
\hline 4 & 174 & 81 & 255 & 228 & 109 & 337 \\
\hline 5 & 160 & 52 & 212 & 199 & 108 & 307 \\
\hline 6 & 201 & 87 & 288 & 263 & 158 & 421 \\
\hline $\begin{array}{c}\text { Total } \\
\text { Average } \\
\text { Score }\end{array}$ & 181 & 81 & 262 & 227 & 124 & 351 \\
\hline
\end{tabular}

Following the objective 2, the researcher has analyzed students' TOEIC results before and after applying Kahoot! as a remedial teaching tool. The results are demonstrated in Tab. 2 .

The results presented in Table 2 show that the total TOEIC average score after applying Kahoot! as a remedial teaching tool is higher than before applying Kahoot!, with the difference score being $25.36 \%$. The percentage of difference score before and after employing Kahoot! in the reading section is more than the difference in the listening section (34.68\% vs. $20.26 \%)$.

The group that obtained the highest difference in percentage is group $6(31.59 \%)$, it is followed by group 5 (30.94\%), $2(24.58 \%), 4(24.33 \%), 3(22.89 \%)$ and $1(17.80 \%)$. In the listening section, the group that obtained the highest difference is group 4 (23.68\%), followed by group 6 (23.57\%), 2 (22.87\%), 5 (19.60\%), 3 (17.21\%) and 1 (14.59\%).

In the reading section, the group that obtained the highest difference is group 5 $(51.58 \%)$, followed by group $6(44.94 \%), 3(33.33 \%), 2(27.48 \%), 4(25.69 \%)$ and 1 $(23.97 \%)$.

After that, the researcher has designed quizzes specifically on the reading section, with incomplete sentences and text completion parts. The findings of Kahoot! application are shown in Tab. 3.

The researcher conducted 15 classes to improve students' TOEIC test-taking skills in reading section, concentrating on incomplete sentences and text completion parts by applying Kahoot! as a remedial teaching tool for 15-20 minutes at the end of each class.

The results shown in Tab. 3 demonstrate that Kahoot! average score, including the percentage of correct answers tends to get higher while the percentage of wrong answers tends to get gradually lower. The average score on Kahoot! is calculated from the speed with which students respond correctly. 
Table 2 -TOEIC Score Results of First-Year Students before and after Applying Kahoot! as a Remedial Teaching Tool

(Source: made by the author)

\begin{tabular}{|c|c|c|c|c|}
\hline \multirow[b]{2}{*}{ Before/after/semester } & \multirow[b]{2}{*}{ Groups } & \multicolumn{3}{|c|}{ TOEIC Average Scores } \\
\hline & & $\begin{array}{c}\text { Listening } \\
\text { (495) }\end{array}$ & $\begin{array}{c}\text { Reading } \\
\text { (495) }\end{array}$ & $\begin{array}{l}\text { Total } \\
(990)\end{array}$ \\
\hline Before applying Kahoot! (Semester 3/2017) & \multirow[t]{3}{*}{1} & 199 & 92 & 291 \\
\hline After applying Kahoot! (Semester 1/2018) & & 233 & 121 & 354 \\
\hline Difference score $(\%)$ & & 14.59 & 23.97 & 17.80 \\
\hline Before applying Kahoot! (Semester 3/2017) & \multirow[t]{3}{*}{2} & 172 & 95 & 267 \\
\hline After applying Kahoot! (Semester 1/2018) & & 223 & 131 & 354 \\
\hline Difference score $(\%)$ & & 22.87 & 27.48 & 24.58 \\
\hline Before applying Kahoot! (Semester 3/2017) & \multirow[t]{3}{*}{3} & 178 & 78 & 256 \\
\hline After applying Kahoot! (Semester 1/2018) & & 215 & 117 & 332 \\
\hline Difference score $(\%)$ & & 17.21 & 33.33 & 22.89 \\
\hline Before applying Kahoot! (Semester 3/2017) & \multirow[t]{3}{*}{4} & 174 & 81 & 255 \\
\hline After applying Kahoot! (Semester 1/2018) & & 228 & 109 & 337 \\
\hline Difference score $(\%)$ & & 23.68 & 25.69 & 24.33 \\
\hline Before applying Kahoot! (Semester 3/2017) & \multirow[t]{3}{*}{5} & 160 & 52 & 212 \\
\hline After applying Kahoot! (Semester 1/2018) & & 199 & 108 & 307 \\
\hline Difference score $(\%)$ & & 19.60 & 51.85 & 30.94 \\
\hline Before applying Kahoot! (Semester 3/2017) & \multirow[t]{3}{*}{6} & 201 & 87 & 288 \\
\hline After applying Kahoot! (Semester 1/2018) & & 263 & 158 & 421 \\
\hline Difference score $(\%)$ & & 23.57 & 44.94 & 31.59 \\
\hline Before applying Kahoot! (Semester 3/2017) & \multirow[t]{3}{*}{$1-6$} & 181 & 81 & 262 \\
\hline After applying Kahoot! (Semester 1/2018) & & 227 & 124 & 351 \\
\hline Difference score $(\%)$ & & 20.26 & 34.68 & 25.36 \\
\hline
\end{tabular}

\section{Conclusion And Discussion}

The researcher has analyzed TOEIC score results of the first-year students, International College, Suan Sunandha Rajabhat University and has found that out of 990 points, the students' average score in semester $1 / 2018$ was higher than the average score back in semester 3/2017.

The students gained higher average scores in the listening section rather than in the reading section. These results are consistent with the study results of Buaphan (2018); Patthamathat, (2015); Lerthiransap, (2017); Ismail \& Mohammad (2017); and Pede (2017).

This means that integrating Kahoot! into the classroom environment can increase students' motivation and attention in learning as well as their learning achievements. In addition, many researchers have investigated students' satisfaction after applying Kahoot! in a classroom.

The results show that students tend to demonstrate high level of satisfaction playing Kahoot! in class (Chakornjirakiat, 2015; Bicen \& Kocakoyun, 2018; Plump \& LaRosa, 2017; Thanh, 2017). According to our class observations, these previous findings are consistent 
with the results in this study: the students now pay more attention to studying, had fun and tried to find correct answers on their own and also discussing answers with their peers.

Besides, they interacted and stated they would like to study by playing on Kahoot! in the next class as well. Since the results in the students' average score in the reading section were lower than those in the listening section, the researcher applied Kahoot! as a remedial teaching tool for this reading section only.

According to the findings of this study, in the future, the researcher should integrate other active and cooperative learning strategies such as peer-assisted learning in class because such methods have already proved their efficiency.

Table 3 - Score Results of Applying Kahoot! as a Remedial Teaching Tool (Source: made by the author)

\begin{tabular}{|c|c|c|c|}
\hline Class & Correct Answer $(\%)$ & Wrong Answer $(\%)$ & Average Score \\
\hline 1 & 26.67 & 73.33 & 493.31 \\
\hline 2 & 33.33 & 66.67 & 666.69 \\
\hline$\underline{3}$ & $\underline{38.18}$ & $\underline{61.82}$ & $\underline{636.55}$ \\
\hline 4 & 34.09 & 65.91 & 585.84 \\
\hline $\mathbf{5}$ & $\mathbf{2 0 . 0 0}$ & $\mathbf{8 0 . 0 0}$ & $\mathbf{2 9 0 . 4 4}$ \\
\hline $\mathbf{6}$ & $\mathbf{1 1 . 1 1}$ & $\mathbf{8 8 . 8 9}$ & $\mathbf{1 6 4 . 7 6}$ \\
\hline 7 & 33.33 & 66.67 & 469.33 \\
\hline $\mathbf{8}$ & $\mathbf{2 7 . 7 8}$ & $\mathbf{7 2 . 2 2}$ & $\mathbf{5 1 7 . 6 3}$ \\
\hline 9 & 34.38 & 65.63 & 686.83 \\
\hline 10 & 46.67 & 53.33 & 777.86 \\
\hline 11 & 41.03 & 58.97 & 874.63 \\
\hline 12 & 42.86 & 57.14 & 1008.00 \\
\hline$\underline{13}$ & $\underline{36.67}$ & $\underline{63.33}$ & $\underline{820.95}$ \\
\hline 14 & 67.05 & 32.95 & 2878.22 \\
\hline 15 & 68.89 & 31.11 & 3298.78 \\
\hline Average & $\mathbf{3 7 . 4 7}$ & $\mathbf{6 2 . 5 3}$ & $\mathbf{9 4 4 . 6 5}$ \\
\hline
\end{tabular}

The researcher has compared TOEIC results before and after applying Kahoot! as a remedial teaching tool and has found that TOEIC scores after applying Kahoot! were higher than the scores before applying Kahoot!, and the percentage of difference in the reading section was higher than that of the listening section. Students in group 5 got the highest percentage of difference while students in group 1 gained the lowest percentage of difference.

Although students in group 5 got low TOEIC results, they still managed to increase their skills of TOEIC test-taking. This may have been due to the fact that TOEIC score results of students in this group were generally low so it is difficult for them to improve their skills in test-taking as such. Moreover, students in group 1 obtained relatively high TOEIC score results but they also got low percentage of difference. This might have been because their TOEIC results even before applying Kahoot! were already quite high so it has been difficult for them to get even higher scores.

On the other hand, students in group 6 gained good TOEIC results, and their percentage of difference was also quite high. It can be concluded that students in this group 


\section{DEVELOPMENT OF TOEIC TEST-TAKING SKILLS BY}

already had some skills in TOEIC test-taking but managed to improve their own skills of test-taking even further.

We also need to keep in mind that apart from interesting and effective remedial teaching tools and the score results before and after applying these remedial teaching tools, other factors may be also significant for improving students' test-taking skills such as previous knowledge, practice, techniques, test timing, and consistency.

The researcher conducted 15 classes to improve students' TOEIC test-taking skills in the reading section, namely through exercises with incomplete sentences and text completion by means of applying Kahoot! as a remedial teaching tool for 15-20 minutes at the end of each class. The results demonstrated that Kahoot! average score, including the percentage of correct answers, tends to get higher while the percentage of wrong answers tends to get lower. The researcher has also found that the average results of correct answers in percentage in some classes actually decreased. It can be concluded that even though students gained lower percentage of correct answers, they were more confident since they obtained more average score on Kahoot! which is calculated taking into account the speed with which students were responding correctly.

\section{Recommendations}

1. The researchers should further investigate the effectiveness, efficiency and satisfaction of applying Kahoot! in teaching and learning by conducting more of mixed method research including surveys, interviews and/or focused group discussions.

2. The researchers should apply other active teaching and learning applications in a classroom in order for students to have better achievement and satisfaction in learning.

3. The researchers should compare students' satisfaction with traditional learning and with active learning. Such results would motivate teachers to integrate new, advanced and effective teaching strategies in their classes.

\section{Acknowledgements}

I would like to express my sincere thanks to Suan Sunandha Rajabhat University for invaluable help throughout this research.

\section{References:}

Bicen, H. \& Kocakoyun, S. (2018). Perceptions of Students for Gamification Approach: Kahoot as a Case Study. International Journal of Emerging Technologies in Learning, 13(2).

Buaphan, K. (2018). Student's Achievement Based on Kahoot Activities in Learning Comparative Politics. Faculty of Political Science, Hadyai University. Songkla: Hadyai University.

Chakornjirakiat, N. (2015). Using Game Test for Comparing Satisfaction towards Testing in the Foundation Course of Computer Programming between Using Kahoot! and Normal Testing of Second Year Vocational Certificate Students. Wanich Business Administration Technological College. Nonthaburi: Wanich Business Administration Technological College.

Educational Testing Service. (2018). The TOEIC Program: The Global Leader in English-Language Assessment for the Workplace. Retrieved from: https://www.ets.org/toeic. 
Ismail, M.A. \& Mohammad, J.A.M. (2017). Kahoot: a promising tool for formative assessment in medical education. Education in Medicine Journal, 9(2), 19-26.

Kahoot!. (2018). What is Kahoot!?. Retrieved from https://kahoot.com/what-is-kahoot.

Lerthiransap, S. (2017). Improving Learning Achievement by Using Kahoot Application in Computer Subject of Grade 12 Students, Demonstration School of Suan Sunandha Rajabhat University. Bangkok: Suan Sunandha Rajabhat University.

Patthamathat, N. (2015). Applying Kahoot to Increase Learning Achievement of Grade 10 Students in Fundamental English.

Pede, J. (2017). The Effects of the Online Game Kahoot on Science Vocabulary Acquisition. Thesis for the Master of Arts in Special Education at Rowan University.

Plump, C. M. \& LaRosa, J. (2017). Using Kahoot in the Classroom to Create Engagement and Active Learning: A Game-Based Technology Solution for eLearning Novices. Management Teaching Review, 2(2), 151-158.

Thanh, L. (2017). Improve Students Engagement and Collaboration with Kahoot. Full text available here: http://www.vnseameo.org/TESOLConference2018/wpcontent/uploads/2018/09/Le_Thanh_Ha-Full-paper-July-10.pdf

Torwong, P. (1995). Trends and Issues in the Teaching of EFL Writing: Where Shall We Go? Journal of Humanities and Social Science, Khonkaen University, 22(3), 115-122.

Paper submitted

Paper accepted for publishing

Paper published online
25 May 2020

19 August 2020

30 September 2020 